\title{
Paramilitary Forces in Colombia
}

Winifred Tate

Colby College,wltate@colby.edu

Follow this and additional works at: https://digitalcommons.colby.edu/faculty_scholarship

Part of the Anthropology Commons, and the Latin American Studies Commons

\section{Recommended Citation}

Tate, Winifred, "Paramilitary Forces in Colombia" (2011). Faculty Scholarship. 62.

https://digitalcommons.colby.edu/faculty_scholarship/62

This Article is brought to you for free and open access by Digital Commons @ Colby. It has been accepted for inclusion in Faculty Scholarship by an authorized administrator of Digital Commons @ Colby. 


\title{
PARAMILITARY FORCES IN COLOMBIA
}

\author{
Winifred Tate \\ Colby College
}

Los señores de la guerra: De paramilitares, mafiosos y autodefensas en Colombia. By Gustavo Duncan. Bogotá: Planeta; Fundación para la Seguridad, 2007. Pp. 368.

Shooting Up: Counterinsurgency and the War on Drugs. By Vanda FelbabBrown. Washington, D.C.: Brookings Institution Press, 2010. Pp. xiv + 273. $\$ 28.95$ paper.

Mafia \& Co.: The Criminal Networks in Mexico, Brazil, and Colombia. By Juan Carlos Garzón. Translated by Kathy Ogle. Washington, D.C.: Woodrow Wilson International Center for Scholars, Latin American Program, 2010. Pp. 187. Available at http://www.wilsoncenter.org/topics/pubs/Mafia\%20and\%20 Company.pdf.

Country of Bullets: Chronicles of War. By Juanita León. Translated by Guillermo Bleichmar. Albuquerque: University of New Mexico Press, 2009. Pp. xxii +223. $\$ 24.95$ paper.

Y refundaron la patria: De cómo mafiosos y políticos reconfiguraron el Estado colombiano. Edited by Claudia López. Bogotá: Random House Mondadori, 2010. Pp. 524. COL\$49,000 paper.

Guerreros y campesinos: El despojo de la tierra en Colombia. By Alejandro Reyes Posada, with Liliana Duica Amaya. Buenos Aires: Grupo Editorial Norma, 2009. Pp. xi + 378. \$28.35 paper.

How can we understand the transformation of Colombian paramilitary groups during the past two decades? Intimately connected to drug trafficking, paramilitary groups have infiltrated political institutions and enjoyed significant political support even as they have used extreme brutality. Since the early 1990s, paramilitaries have grown exponentially in strength, creating a national coordinating body and carrying out military offensives. These developments brought territorial expansion throughout Colombia and a peak in political violence, typified by massacres from 1997 to 2003. After negotiations with government officials, more than thirty-two thousand troops passed through demobilization programs verified by the Organization of American States; much of the high-profile leadership was subsequently extradited to the United States to face charges of drug trafficking. Revelations of electoral fraud resulted in the so-called parapolitica scandal, in which hundreds of politicians were indicted for collusion with paramilitary forces. Colombian and U.S. officials claim gains in the consolidation of democracy, even as journalists and others document ongoing paramilitary activity. 
It is critical for scholars and policy makers hoping to understand contemporary Colombia to examine the role that political and economic structures have played in these developments, including the unintended consequences of efforts to foster democracy in the region and the deep connections between illicit economies and public life. This history also serves as a case study of the intersection of political and criminal violence, organized crime, and comparative practices of governance useful for Mexico, Brazil, and beyond.

Many gaps remain in the literature about the role and evolution of paramilitary forces. ${ }^{1}$ In part, this reflects the difficulty of researching violent illicit economies and the degree to which public discussion of these issues is ideologically driven. ${ }^{2}$ The books examined here, particularly those by Colombian scholars, offer important insights into structural links between paramilitary expansion, democratization efforts, and local governance, building on the groundbreaking studies of Mauricio Romero. ${ }^{3}$ The two most ambitious books, Gustavo Duncan's Los señores de la guerra and Claudia López's massive collection of essays Y refundaron la patria, argue that paramilitary forces (or warlords, in Duncan's typology) are the result of dramatic changes in Colombia's economic and political landscape, and of reconfigured statehood and governance in many regions. Alejandro Reyes Posada's Guerreros y campesinos addresses the critical issues of land ownership and displacement. This book is of particular interest because of the author's current role as adviser to the Santos administration's land redistribution program. The two works in translation make available to English speakers the tales of conflict gathered by award-winning Colombian journalist Juanita León and the policy recommendations of Juan Carlos Garzón, who weaves in stories from Mexico, Brazil, and Colombia. Shooting Up: Counterinsurgency and the War on Drugs, by Brookings Institute analyst Vanda Felbab-Brown, includes chapters on Colombia, Peru, and Afghanistan to explain how U.S. policy has collapsed counterinsurgency and counternarcotics efforts.

A key issue in these analyses is typology: how does one classify the dizzying

1. Carlos Medina Gallego wrote one of the few studies of the origins of regional paramilitarism in Colombia in Autodefensas, paramilitares y narcotráfico en Colombia: Origen, desarrollo y consolidación: el caso "Puerto Boyacá" (Bogotá: Editorial Documentos Periodísticos, 1990); another early analysis is Francisco Cubides, "Los paramilitares y su estrategia," in Reconocer la guerra para construir la paz, ed. María Victoria Llorente and Malcolm Deas (Bogotá: Grupo Editoral Norma, 1999), 151-199. Several Web sites provide ongoing current analysis, including Verdad Abierta (http://www.verdadabierta.com), focused on paramilitaries and armed conflict in Colombia, and InSight (http://www.insightcrime.org), on organized crime in the Americas.

2. Francisco Thoumi, "The Numbers Game: Let's All Guess the Size of the Illegal Drug Industry!" Journal of Drug Issues 35, no. 1 (2005): 185-200; Peter Andreas, “The Politics of Measuring Illicit Flows and Policy Effectiveness," in Sex, Drugs and Body Counts: The Politics of Numbers in Global Crime and Conflict, ed. Peter Andreas and Kelly M. Greenhill (Ithaca, NY: Cornell University Press, 2010), 23-45; Winifred Tate, "Accounting for Absence: The Colombian Paramilitaries in U.S. Policy Debates," in Sex, Drugs and Body Counts: The Politics of Numbers in Global Crime and Conflict, ed. Peter Andreas and Kelly M. Greenhill (Ithaca, NY: Cornell University Press, 2010), 215-246.

3. Mauricio Romero, Paramilitares y autodefensas, 1982-2003 (Bogotá: Instituto de Estudios Políticos y Relaciones Internacionales, 2003); Mauricio Romero, ed., Parapolítica: La ruta de la expansión paramilitar y los acuerdos políticos, 2nd ed. (Bogotá: Corporación Nuevo Arco Iris, 2007). 
array of paramilitary groups commonly called self-defense forces, warlords, military entrepreneurs, mafias, gangs, bandits, and so on. Factors in attempting to distinguish among these groups are funding; their penetration in legal and illegal economies; their relationship to the state and their autonomy vis-à-vis political and military institutions; their internal hierarchy, command structure, and geographic reach; and their economic and political objectives. ${ }^{4}$ Such groups also vary widely by region and over time, morphing from one identity to another. Noting these difficulties, most analyses employ the term paramilitary to put the focus on the historic alliance of these groups with official security forces. Ariel Fernando Ávila Martínez adds the term narcoparamilitary to emphasize the role of drug trafficking (in López). Garzón (24) cites the "blurry boundaries" between groups and argues that a more important distinction is the group's internal structure, which he describes as following either the "Godfather model" (hierarchical, authoritarian) or the "Facebook model" (dynamic, networked).

Duncan offers the most ambitious and comprehensive typology, asserting that Colombian groups evolved from death squads and personal-security details to paramilitaries and finally warlords, that is, from hired protection services to groups with their own command structure to autonomous statelike actors. He also distinguishes such groups from mafias, which attempt to control economic transactions but not the state. Of Colombian traffickers, Duncan claims that only Pablo Escobar attained mafia status. In what he describes as an unprecedented development, Colombian paramilitaries became autonomous armies with their own doctrine, chain of command, iconography (e.g., uniforms, emblems, hymns), sophisticated weaponry, and most important, the aim to regulate social life in the regions where they operate. According to Duncan, Carlos Castaño was the central figure in this transformation, but even he was unable to impose a national vision (including a national command structure) on disputing regional factions, and thus did not implement complete paramilitary governance.

Duncan's conclusions raise several issues that his analysis does not satisfactorily answer, in part because it is unclear to what degree he draws on his own fieldwork or instead on secondary sources. Although becoming a warlord may have been Castaño's aspiration, this ambition was not realized according to Duncan's own accounting; so does the label aptly describe what happened in Colombia? Duncan's evolutionary model also does not seem to fit the fluid and fractured nature of Colombian violence. This highlights one of the most controversial issues regarding Colombian paramilitary groups: the degree of autonomy that they maintained from other political and economic powers, and their capacity to regulate social life as a statelike power in the areas under their control. More regional case studies are required to test these assertions.

4. Julie Mazzei develops a model of paramilitary groups emerging from the space between civil society and the state to defend particular economic and political interests, but her consideration of Colombia does not adequately address the complexities of these relationships in Death Squads or Self Defense Forces? How Paramilitary Groups Emerge and Challenge Democracy in Latin America (Chapel Hill: University of North Carolina Press, 2009). 


\section{PARAMILITARY ECONOMICS}

Colombian paramilitaries emerged from and participate in the illegal trade in narcotics, yet not all drug traffickers are paramilitaries. Each of the books under review links changes in paramilitary structures to those in the drug trade, as larger cartels were dismantled in the 1990s and new traffickers required greater private security. These books also explore the paramilitaries' evolving ties to the legal economy, especially through land tenure.

The latter is the focus of Reyes Posada, who draws on three decades of his own research, surveys of land sales, two interviews with the Castaño brothers, and newspaper columns. Reyes illustrates the history of violent regional conflict with his well-known maps, arguing that conflict was fundamentally about territorial control. More detailed consideration of the impact that conflict has had on land use and the rural economy could strengthen this claim. Reyes Posada traces a fundamental change in the ways peasants have organized to protect their interests. For much of the twentieth century, peasants sought access to land, challenging latifundistas by invading their holdings and through social organization. These practices declined in the face of escalating conflict, and current efforts focus on protecting campesinos from violent displacement as armed actors consolidate their control. Reyes tracks how profits from the drug trade facilitated a form of reverse agrarian reform. Traffickers purchased massive tracts of landReyes estimates that they hold more than 12 percent of Colombia's territory-to launder their profits and enhance their social status. Increasing land concentration, inflated prices, decreased investment in agriculture, and inefficient land use (because of its conversion to cattle ranching) are among the effects that Reyes Posada discusses. Narco-landowners played a central role in the growth of paramilitary forces, which were contracted to protect them and their trafficking and other business interests from guerrilla extortion.

Reyes Posada also illuminates the role of paramilitaries in restructuring land ownership through violence and explicit attempts at land redistribution. He explains that paramilitaries appropriate land to increase their wealth and security, repopulating it with people loyal to them while creating sanctuaries for their business interests, including drug trafficking and ranching. In contrast, although guerrillas occasionally appropriate land, they are more likely to abandon it for tactical reasons, using stolen goods, including cattle and vehicles, as liquid capital to fund their military operations. Reyes Posada documents the difficulties inherent in redistribution efforts, including threats, the extremely complex ownership and occupation histories of properties inhabited by multiple families as a result of displacement and armed resettlement, and the intentional destruction of land titles by the burning of land registry offices in several regions.

Duncan views this intersection of paramilitary and economic forces through a wider lens, arguing that warlords emerged from a deep division between the capitalist development of rural areas and that of urban centers. In part because of structural changes in Colombia's economy in the 1990s, legal agrarian production could not compete with the lucrative trade in illicit drugs. At the same time, warlords easily adopted agrarian "values," including clientelism, reliance on private 
justice, and acceptance of inequality before the law. Some regions also had long histories of using violence and private armies as political tools, dating from the La Violencia (1946-1966) and earlier. The consolidation of wealth arising from the expansion of narcoparamilitaries into secondary investments further distorts local economies, thus preventing industrial and infrastructure development and what Duncan (81) calls "rational" capitalism.

\section{PARAMILITARY POLITICS}

The economic opening of the 1990s was only one of the structural changes that led to the emergence of paramilitaries and new political arrangements. For example, reforms that ended the National Front hegemony of two traditional parties and centralized political power were "co-opted by illegal interests," including drug trafficking and other businesses at the margin of the law (Duncan, 113).

The most detailed work to date on the interests that now dominate Colombia's political system is that of investigative journalist López and her team of researchers. The overarching argument of the essays in her collection is expressed in the subtitle: "De cómo mafiosos y políticos reconfiguraron el Estado colombiano." Contributions address such matters as the role of illegal groups in Colombian politics, power networks in Casanare and the Atlantic Coast, the conduct of congressional politicians linked to paramilitary forces, and the role of judiciary. The book comes with a CD-ROM of case studies of individual departments, an invaluable resource for examining the links between political violence and elections in greater detail.

López's introduction reprises her now-famous examination of voting records that revealed "atypical voting patterns," widespread electoral irregularities eventually linked to the collusion of paramilitaries and politicians (27). By April 2010, 400 elected officials, including 102 members of congress, were under investigation in the so-called parapolítica scandal, as well as 324 members of the armed forces and 5,766 private citizens. Approximately one-third of Colombia's mayors, governors, and congressional representatives were elected with the support of paramilitaries; almost all of these officials were reelected in 2006. In comparison, when the wide-ranging corruption committed during the 1994 presidential campaign of Ernesto Samper Pizano was exposed-a scandal that caused the U.S. State Department to decertify the Colombian government in its annual assessment of counternarcotics cooperation-a total of sixteen politicians were sentenced for illicit enrichment.

The parapolítica scandal raises several issues. The contributors to López's volume argue, first of all, that the relationship between paramilitaries and politicians was the inverse of that usually imagined: rather than illegal actors buying their way into the political system, in the Colombian case, politicians saw the growing power of paramilitary forces and approached them about forging an electoral alliance. Luis Jorge Garay insists, moreover, that the traditional model of state capture focused on the activities of legal groups fails to explain the Colombian dynamic, thus leading him to propose an alternative scheme of "co-opted state reconfiguration," in which illegal groups use both bribery and violence, not only to further their business interests but also to gain impunity for their crimes 


\section{Latin American Research Review}

as well as political and social legitimacy (López, 215-221). ${ }^{5}$ This analysis prompts one to ask whether this is a new phenomenon or instead an expansion of existing forms of state capture. What defines legitimacy and the public interest in Garay's model? Finally, the normative judgment and lack of clarity inherent in the concepts discussed make Garay's distinction between "perverse social capital" and "social capital" (López, 221-223) all but useless.

Using official testimony before the offices of the attorney general and inspector general, the contributors to Y refundaron la patria make a complex socialnetworking analysis of the two regions mentioned already. These illuminate what Duncan refers to as "armed clientalism" (281), in which an emerging class of local power brokers able to provide economic benefits mediates the relations of state and citizen.

Another question arising from the parapolítica scandal is how the political activities of guerrillas and paramilitaries differ. Unlike Peru, where the study of Sendero Luminoso has emerged as an academic subdiscipline, there has been remarkably little scholarly analysis of Colombian guerrillas, with even less available in English. According to both Duncan and Ávila Martínez, guerrillas and paramilitaries differ in their political objectives, strategies, and alliances. Duncan sees this as degrees of political power: the guerrillas want national power, which requires a cohesive military command structure, whereas paramilitaries want a regional power base from which to negotiate inclusion in the elite. In his masterful summation of the political strategies of paramilitaries, the Revolutionary Armed Forces of Colombia (Fuerzas Armadas Revolucionarias de Colombia, or FARC), and the National Liberation Army (Ejército de Liberación Nacional, or ELN), Ávila Martínez notes that guerrillas have an antistate, anticapitalist project; their social capital is largely limited to the marginalized poor. Thus, even though the FARC and ELN pioneered the strategy of co-opting local bodies such as juntas de acción communal and of pressuring mayors and municipal bureaucrats for financial and political resources to attain particular goals, their political penetration has largely been restricted to the municipal level, with little or no urban or elite links to the national state. Paramilitary groups, in contrast, are pro-state and pro-capitalist, with sophisticated, increasing, and influential social capital. They successfully use electoral, political, and public institutions as a means to their objectives on the national, departmental, and local levels.

This analysis, which rightly considers the critical support of the middle and upper classes, is in marked contrast to that made by Felbab-Brown in treating the differences between guerrillas and paramilitaries. She focuses on political capital, which she defines as the freedom to act with support from the local population. She concludes that FARC's participation in the illicit economy increased its political capital among rural peasant farmers, although this is now eroding as a result of FARC's draconian treatment of rural peoples and its failure to defend them from paramilitary attacks. Focusing on the efforts of paramilitaries to

5. A summary of Garay's argument is available in English as "From State Capture towards the Coopted State Reconfiguration: An Analytical Synthesis," Método Working Paper No. 61 (2009), at http:// papers.ssrn.com/sol3/papers.cfm?abstract_id=1410865. 
conquer drug-producing regions, she notes that they "sided with the traffickers, not the local population" (97). Explicitly written for readers in the United States concerned with formulating policy, Felbab-Brown's account unfortunately typifies the failure to assess the extent of support for paramilitaries by the political elite and middle class.

Another fundamental question arising from the parapolítica scandal is its relationship to uribismo, the movement centered on President Álvaro Uribe Pérez (2002-2010). The painstaking analysis in six chapters in Y refundaron la patria of legislative action by members of congress implicated in the scandal leads the researchers to conclude that there was not a paramilitary block per se. Politicians supported by paramilitaries did not have a collective legislative agenda but did tend to serve on a specific set of committees, including appropriations, judicial and political reform, and agrarian issues. In this, they helped consolidate the power of the executive, following Uribe's lead in a series of controversial bills, including the constitutional amendment allowing for his reelection and the so-called Peace and Justice Law, which set the terms for paramilitary demobilization.

\section{POLICY ARGUMENTS}

Garzón's many fascinating tales of traffickers and their communities provide a scattered introduction to the prevalence of organized crime in Mexico, Brazil, and Colombia. He is less successful in addressing the role of economic change and democratization in this phenomenon. A lack of structure and incomplete citations mar his analysis. The central section, bizarrely titled "The Rebellion of the Shapes," is framed with the tautological argument that "certain forms [of organized crime] have been able to emerge (because of a combination of elements found in the legal and illegal worlds) and to continue to exist (because they are compatible with the reality in which they emerge and develop) in a context of uncertainty" (33). His discussions of connections between licit and illicit markets, of government regulatory power, of new markets, and of "the political-criminal nexus" (136-137), a concept borrowed from Roy Godson, are underdeveloped and do not come until the final section. ${ }^{6}$

Felbab-Brown seeks to combat the conventional view that insurgents receive large profits from drug-trafficking organizations and are therefore vulnerable to a counternarcotics campaign targeting this resource base. Offering a welcome corrective to the growing greed-versus-grievance literature on civil wars, FelbabBrown argues that the narcoguerilla thesis leads to ineffective and even counterproductive policies because, despite criminal activities, guerrillas maintain their insurgent goals. In the case of Colombia, Felbab-Brown disputes claims that successes against FARC are due to U.S. drug policy and crop eradication, arguing instead that military assistance has been key. Her discussion of paramilitary groups does not adequately address their role in politics or the implications of their participation in counterinsurgency efforts. 
By focusing on current debates especially in the United States, Garzón and Felbab-Brown are unable to explain the origins and impact of the wrongheaded policies that they seek to refute. For example, Garzón suggests that "politicians, analysts, and academics unaware of its true dimensions continue treating [organized crime] as if it were a matter of 'cops and robbers'" (172). However, it is not ignorance, but ideology, that drives U.S. drug policy, as a growing number of studies attest. Although Felbab-Brown argues persuasively that eradication policies have failed and "counternarcotics and counterinsurgency strategies often are at odds" (178), she does not address the multiple ways in which counternarcotics policies have contributed to particular forms of organized crime, including paramilitary forces. She mentions the origin of the term narcoguerrilla but does not explain that this label is a prerequisite for U.S. military assistance, nor does she explore the irony of U.S. support for military forces linked to drug-trafficking paramilitaries. These silences are perhaps understandable, given that both authors target readers unreceptive to such matters; nevertheless, they limit the usefulness of the analyses to a scholarly audience.

Other notable absences in the books under review include the roles of gender, race, and the impact of new power brokers on the daily lives of citizens. With the exception of León, all treat Colombia as though it were undifferentiated except by region and class by focusing on a peasant-urban divide. They privilege major charismatic leaders and ignore their followers. ${ }^{7}$ The absence of indigenous and Afro-Colombian communities is particularly striking, as their collective land rights have made them particularly vulnerable to displacement. ${ }^{8}$ These rights have also facilitated innovative responses, such as the civil resistance of Cauca Indians profiled by León. Although ethnographic analysis presents significant methodological challenges, it can bring much to the study of paramilitaries. For example, Duncan claims that new forms of citizenship have arisen where paramilitaries are in control, with formal and informal norms that dictate the duties and rights of residents. Duncan calls this citizenship volatile because of the constant flux of military superiority: "no hay disponsibilidad de tiempo para establecer un dominio social basado en reglas y principios acordados a través de canales regulares entre la población y sus gobernantes" (139). It is unclear, however, how volatile citizenship functions in practice. How are social and political norms transmitted? To what degree are they regularized or arbitrary, determined by the whim of particular commanders? Can a transient power in fact establish new forms of citizenship? How does the local population experience these forms? These questions are critical for understanding how paramilitary forces are reshaping political culture in Colombia, but they cannot be answered without extensive fieldwork.

Some clues to the complexity of life in Colombian combat zones are found in León's dramatic and tragic tales. Here, the voices of individual men and women,

7. For a troop-level analysis, see Kimberly Theidon, “Reconstructing Masculinities: The Disarmament, Demobilization, and Reintegration of Former Combatants in Colombia," Human Rights Quarterly 31, no. 1 (2009): 1-34.

8. See Bettina Ng'weno, Turf Wars (Palo Alto, CA: Stanford University Press, 2007); Arturo Escobar, Territories of Difference (Durham, NC: Duke University Press, 2008). 
peasants, community leaders, taxi drivers, mothers and fathers, recount the terrible cost of negotiating between and among competing powers. León's accounts provide snapshots of various regions between 2000 and 2005. By focusing on civilians caught in the cross fire, she emphasizes not their impotence but the choices made daily; these can be a small-town mayor dealing with thousands of displaced peasants, a former guerrilla navigating his hometown after a paramilitary takeover, or squabbling siblings forced to face guerrilla justice. Although informed by a deep knowledge of contemporary political life in Colombia, she does not, as a journalist writing for a general American audience, include a structural historical analysis like that the other authors under review provide.

\section{TOWARD A NEW SCHOLARSHIP OF PARAMILITARISM}

Although many works examining the recent growth of private militaries point to global shifts in the context and technologies of conflict, the studies reviewed here argue that we must look to historical conditions within Colombia. To understand the emergence of illegal armed groups-narcoparamilitaries, mafias, warlords-one must join the analysis of shifting forms of organized crime to broader structural changes in the economy and politics. The growing body of literature by Colombian scholars offers a critical base for this understanding, but many questions remain.

How deep and lasting is the reconfiguration of the state by paramilitary forces? Only time will tell. Paramilitaries relate to governmental agencies and institutions in various ways. In the case of the parapolitica scandal, military officers and high-ranking politicians showed a shared sense of purpose and strategic interests. Researchers in López document judicial corruption and capture by illegal armed groups (including "corruption by fear," as they refer to the pervasive threats, intimidation, and physical attacks that the Colombian judiciary faces), as well as many important instances in which judges and magistrates resisted pressure and maintained their autonomy. Evidence that members of congress tied to paramilitaries followed the executive's lead also raises questions about the role of the Uribe administration in reconfiguring the state.

Are paramilitaries an effective counterinsurgency force? Ávila Martínez writes that paramilitary groups were characterized by a "un discurso contrainsurgente que, en muchos casos, no se cumplió" (in López, 90), in part because of the minimal combat between guerrillas and paramilitaries. Duncan and others instead argue that paramilitaries were instrumental in conquering territory previously dominated by guerrillas, particularly in the case of ELN, even as paramilitaries engaged in other economic and political activities. With the exception of Garzón and Felbab-Brown, all the authors under review contend that counterinsurgency rhetoric, regardless of the efficacy of paramilitaries in practice, increased their political capital among the middle and upper classes. The depth of this support, how counterinsurgency operations function in different regions, and the impact on the FARC remain critical pieces of future research. 


\section{Latin American Research Review}

Finally, what is the future of Colombian paramilitary forces? To predict whether and how these groups will reemerge in the coming decade, one must understand their history and the degree to which they have succeeded in building political and economic support beyond the control of individual leaders. The authors under review agree that demobilization, focused on troops, has failed to alter the structural forces that led to the development of paramilitaries. The extradition of many senior leaders has left a power vacuum. One possibility is the resurgence of mafias, as fewer combatants are required to protect the interests of these groups, which remain entrenched in the illicit economy. Clearly, factors such as the drug trade, regional inequality, and widespread recourse to private security to guarantee access to land and resources are substantially unchanged. From these studies, it appears that the political culture in Colombia that tolerated and in some cases celebrated paramilitaries also remains intact. 